\title{
Determination of Azoxystrobin Residue by UV Detection High Performance Liquid Chromatography in Mango
}

\author{
S. Sundravadana, ${ }^{*, a}$ D. Alice, ${ }^{a}$ R. Samiyappan ${ }^{a}$ and S. Kuttalam ${ }^{b}$ \\ ${ }^{a}$ Department of Plant Pathology, ${ }^{b}$ Department of Agricultural Entomology, \\ Centre for Plant Protection Studies, Coimbatore 641 003, Tamil Nadu, India
}

\begin{abstract}
O resíduo de azoxistrobina em mangas foi determinado por cromatografia líquida de alta performance (HPLC). O resíduo foi extraído com acetonitrila e purificado tanto por extração líquidolíquido (LLE) quanto por extração de fase sólida (SPE). A análise cromatográfica foi realizada em uma coluna ODS2 com fase móvel acetonitrila: água 80:20 v/v e detecção por UV em $255 \mathrm{~nm}$. As recuperações médias e limites de determinação foram iguais a $85.57 \%$ e $0.004 \mu \mathrm{g} \mathrm{g}^{-1} \mathrm{de}$ amostra, respectivamente. Os resultados reveleram que a meia vida da azoxistrobina foi igual a um dia, para a dose recomendada. Portanto, não há problemas de contaminação da cadeia alimentar e do meio ambiente pela adição de azoxistrobina em mangas.
\end{abstract}

Azoxystrobin residue was determined in mango fruits using high performance liquid chromatography (HPLC). Residues of azoxystrobin were extracted with acetonitrile and purified by both liquid liquid extraction (LLE) and solid phase extraction (SPE) clean up. The HPLC analysis was carried out on ODS2 column with acetonitrile: water (80:20 v/v) as the mobile phase with UV detection at $255 \mathrm{~nm}$. The rate of average recoveries and limits of determinations were $85.57 \%$ and $0.004 \mu \mathrm{g}$ per $\mathrm{g}$ of sample, respectively. The results revealed that the half life of azoxystrobin in mango fruit was one day for recommended dose, hence no concern regarding contamination of the food chain and environment by azoxystrobin

Keywords: azoxystrobin, fungicide, HPLC-UV, mango

\section{Introduction}

Azoxystrobin,(Table 6) a natural product from wooddecaying mushroom fungi, Strobilurus tenacellus (Pers. ex Fr.) Singer., ${ }^{1}$ has a broad spectrum of activity against fungal diseases in leading crops like rice, wheat, fruits (mango, apple, vines), vegetables, peanuts etc. ${ }^{2}$ It was reported that, spraying of azoxystrobin ( $75 \mathrm{mg}$ a.i per L) significantly suppressed mango anthracnose (Colletotrichum gloeosporioides Penz.) and increased yield. ${ }^{3}$ On the other hand, fungicides application can leave chemical residue results in acute or chronic health risk on consumption. Hence study of residual analysis is indispensable, to know the residual level, such that the amount does not exceed maximum residue level (MRL) specified for individual chemicals.

Gas chromatography (GC) is the most commonly adopted analytical technique for determination of residues in fruits and vegetables. GC under micro electron capture

*e-mail: sundravadana@rediffmail.com detection $(\mu$-ECD) was found to be effective in determining azoxystrobin residues in apples. ${ }^{4}$ The present study aimed at the determination of azoxystrobin residues in mango fruits by solid phase extraction clean up coupled liquid chromatography (LC)-UV detection.

\section{Experimental}

\section{Analytical standards and working solution}

Standard stock solution was prepared by dissoving analytical standard azoxystrobin $\left(\mathrm{C}_{22} \mathrm{H}_{17} \mathrm{~N}_{3} \mathrm{O}_{5} ; 96 \%\right.$ purity $)$ in acetone and stored at $-20^{\circ} \mathrm{C}$. Working solution was prepared by diluting the standard stock solution with acetone, which was then used for sample fortification $(0.05,0.1$ and $0.2 \mathrm{mg}$ per $\mathrm{kg}$ ) and for injection in the LC system.

\section{Treatment conditions}

Field experiments were carried out under Random- 
ized Block Design with three replications. Three doses of azoxystrobin $25 \mathrm{SC}$ (suspension concentrates) viz., $0.25 \mathrm{~mL}$ per $\mathrm{L}$ (lower dose); $1.0 \mathrm{~mL}$ per $\mathrm{L}$ (recommended dose); $2.0 \mathrm{~mL}$ per $\mathrm{L}$ (double the recommended dose) were sprayed.

\section{Sample preparation}

Fruit samples were collected randomly from the experimental plots, at $0,1,3,5,7,10$ and 14 days after last spray.

\section{Extraction and clean up procedures}

Mango fruits samples (25 g) were transferred into the glass jar and homogenized with acetonitrile: water (90:10 v/v). Then macerate was filtered through a Buchner funnel over laid with what man No.1 filter paper to a round bottom flask with mild suction to separate the sediments and aliquot. The aliquot was collected, quantified to $200 \mathrm{~mL}$ with acetonitrile: water $(90: 10 \mathrm{v} / \mathrm{v})$. To get the clear organic phase, partitioning with an equivalent volume of dichloromethane plus $1 / 2$ equivalent volumes of $5 \% \mathrm{NaCl}$ solution in a separating funnel for about $1 \mathrm{~min}$, filtered through $20 \mathrm{~g}$ of anhydrous $\mathrm{Na}_{2} \mathrm{SO}_{4}$ and evaporates to dryness under reduced pressure. The residue was redissolved in hexane: dichloromethane (50:50) and transferred to solid phase extraction (SPE) clean up to separate out interfering substances. The silica cartridge was conditioned with $5 \mathrm{~mL}$ of hexane: dichloromethane $(50: 50 \mathrm{v} / \mathrm{v})$ followed by sample loading and washing with $5 \mathrm{~mL}$ of dichloromethane and ethyl acetate (90:10 v/v). Azoxystrobin was eluted from the SPS cartridge using $5 \mathrm{~mL}$ of dichloromethane and ethyl acetate $(70: 30 \mathrm{v} / \mathrm{v})$. The elute was evaporated to near dryness and quantified with $1 \mathrm{~mL}$ of acetonitrile and aliquot $(20 \mu \mathrm{l})$ was injected into the LC-UV system.

\section{Recovery studies}

The method described for sample preparation was validated by a recovery investigation. Untreated mango samples were fortified with known amounts of azoxystrobin $(0.05$, 0.1 and $0.2 \mathrm{mg}$ per $\mathrm{kg}$ ) and processed according to the above procedure. Every recovery was done on five replicates.

\section{Instrumentation}

Chromatographic analysis was carried out using a Hitachi mobile L 6200 HPLC equipped with UV detection which was set at $255 \mathrm{~nm}$. The system equilibrium was achieved with acetonitrile (HPLCgrade): Double distilled water (80:20 v/v mobile phase) at $1 \mathrm{~mL}$ per min flow rate.

The following operation conditions and equipment were used: low pressure gradient pump at $350 \mathrm{psi}$; isotherm at room temperature; OD S2 Lichro sphere ${ }^{\circledR}$ 60-RP, select B(5 $\left.\mu \mathrm{m}\right)$ 250-4(ID) Column; $20 \mu \mathrm{L}$ (fixed loop) injection and a D 2500 Hitachi Integrator.

\section{Results and Discussion}

In early studies, determination of azoxystrobin residue done by GC in fruits. ${ }^{4}$ But comparison of HPLC over Gas Chromatography, less volatile and larger samples can be used with HPLC. It was discovered that better separation of the components of the mixture occurs if the particles in the stationary phase are very small. However, it was also found that if very small particles were used in the column, then the liquid passed very slowly through the column. Therefore, a pump is used to force the liquid through the column. This is not necessary in GC but a shorter column can be used in HPLC because the separation is more efficient. Hence the present study carried out to determined azoxystrobin residue by UV detection HPLC in mango.

\section{Determination and recoveries}

The performance of HPLC method was assessed by evaluating quality parameters, such as recovery values and limits of detection (LOD). Recoveries of azoxystrobin at different fortification levels, i.e., 0.05, 0.1 and $0.2 \mathrm{mg}$ per $\mathrm{kg}$, were determined from mango samples. There is no interfering beaks were observed on the chromatogram of the samples under the selected conditions. The recoveries obtained for mango fruit was in the average range of 81.94-97.91\%, LOD was $0.002 \mu \mathrm{g}$ per $\mathrm{g}$ of samples, given in Table 1.

\section{Azoxystrobin residues in mango fruits}

Mango fruit samples which is collected from the field were extracted with acetonitrile: water $(90: 10 \mathrm{v} / \mathrm{v})$ and cleaned-up through a SPE silica column. Then $20 \mu \mathrm{l}$ volumes of aliquot injected into the LC and adjust the UV absorption at $255 \mathrm{~nm}$. The chromatograms from the LC shows the persistence of azoxystrobin in mango fruits, from the results azoxystrobin at recommended dose $(1.0 \mathrm{~mL}$ per $\mathrm{L})$ and double the recommended dose $(2.0 \mathrm{~mL}$ per $\mathrm{L})$ persist up to three days but the lower dose $(0.25 \mathrm{~mL}$ per $\mathrm{L})$ did not persist even at that day of spraying (Table 2). Then initial deposit for both concentrations 0.4296 and 0.9067 $\mu \mathrm{g}$ per $\mathrm{g}$, reached below detectable level (BDL) $5^{\text {th }}$ day 
Table 1. Recovery percentage of azoxystrobin in fortified mango samples

\begin{tabular}{|c|c|c|c|c|c|c|}
\hline \multirow{2}{*}{ Crops } & \multirow{2}{*}{ Particulars } & \multicolumn{3}{|c|}{ Azoxystrobin recovery $\%$} & \multirow{2}{*}{ Mean recovery } & \multirow{2}{*}{$\begin{array}{c}\text { Recovery factors } \\
\text { RF }\end{array}$} \\
\hline & & $0.05 \mathrm{mg}$ per $\mathrm{kg}$ & $0.1 \mathrm{mg}$ per $\mathrm{kg}$ & $0.2 \mathrm{mg}$ per $\mathrm{kg}$ & & \\
\hline Mango & Fruits & 81.94 & 87.08 & 87.68 & 85.57 & 1.17 \\
\hline
\end{tabular}

LOD $0.002 \mu \mathrm{g}$ per $\mathrm{g}$ of sample.

Table 2. Persistence of azoxystrobin in mango fruits

\begin{tabular}{cccc}
\hline \multirow{2}{*}{$\begin{array}{c}\text { Days After } \\
\text { Spray }\end{array}$} & \multicolumn{3}{c}{ Azoxystrobin residues $\mu \mathrm{g}$ per $\mathrm{g}$ of samples } \\
\cline { 2 - 4 } & $0.25 \mathrm{~mL}$ per $\mathrm{L}$ & $1.0 \mathrm{~mL}$ per $\mathrm{L}$ & $2.0 \mathrm{~mL}$ per $\mathrm{L}$ \\
\hline 0 & 0.0183 & 0.4296 & 0.9067 \\
1 & $\mathrm{BDL}$ & 0.3652 & 0.7002 \\
3 & $\mathrm{BDL}$ & 0.0358 & 0.0042 \\
5 & $\mathrm{BDL}$ & $\mathrm{BDL}$ & $\mathrm{BDL}$ \\
7 & $\mathrm{BDL}$ & $\mathrm{BDL}$ & $\mathrm{BDL}$ \\
\hline
\end{tabular}

BDL - Below Detectable level; LOD $0.002 \mu \mathrm{g}$ per g of samples

Table 3. Dissipation of azoxystrobin residues in mango fruits

\begin{tabular}{cccc}
\hline \multirow{2}{*}{$\begin{array}{c}\text { Days After } \\
\text { Spray }\end{array}$} & \multicolumn{3}{c}{ Dissipation of azoxystrobin residues $(\%)$} \\
\cline { 2 - 4 } & $0.25 \mathrm{~mL}$ per $\mathrm{L}$ & $1.0 \mathrm{~mL}$ per $\mathrm{L}$ & $2.0 \mathrm{~mL}$ per $\mathrm{L}$ \\
\hline 0 & - & - & - \\
1 & 100.00 & 14.99 & 22.77 \\
3 & 100.00 & 91.67 & 76.75 \\
5 & 100.00 & 100.00 & 99.53 \\
7 & 100.00 & 100.00 & 100.00 \\
\hline
\end{tabular}

$(1.0 \mathrm{~mL} \operatorname{per} \mathrm{L})$ and $7^{\text {th }}$ day $(2.0 \mathrm{~mL}$ per $\mathrm{L})$ after treatment, respectively. Dissipation pattern of azoxystrobin residue in mango fruits shown in Figure 1. Recommended dose of azoxystrobin dissipated up to $91.67 \%, 3$ days after spray (Table3). Based on the declined behavior of azoxystrobin, seven transformations of azoxystrobin residue was computed. The modified regression co-efficient $\left(\mathrm{MR}^{2}\right)$ of determination were 0.8286 and 0.7599 , respectively for $1 \mathrm{~mL}$ per $\mathrm{L}$ and $2 \mathrm{~mL}$ per $\mathrm{L}$ and best fitted for both concentrations was Inverse Power Law (IPL) (Table 4). The half-life ( $\left.\mathrm{T}_{0.5}\right)$ and waiting period for recommended dose of azoxystrobin were 1.25 and 1.92 days, respectively (Table 5). Considering the Australian Pesticide and Veterinary Medicines Authority (APVMA) established maximum residue limits (MRLs) for azoxystrobin mango $0.05 \mathrm{mg}$ per $\mathrm{kg},{ }^{5}$ the suggested waiting period after spraying of azoxystrobin two day in accordance with good agricultural practices (GAP). The results showed that azoxystrobin was rapidly metabolized in mango fruits. The same way Chen et al. determined residue of azoxystrobin on Chinese cabbage, declined from 4.10 to $0.63 \mathrm{mg}$ per $\mathrm{kg}$ with 18 days and from 13.21 to $0.10 \mathrm{mg}$ per $\mathrm{kg}$ with in 9 days on Chinese kale. ${ }^{6}$

Table 4. Regression Coefficient of azoxystrobin residues in mango fruits

\begin{tabular}{|c|c|c|c|c|c|c|c|c|c|c|c|c|c|c|c|}
\hline \multirow{2}{*}{$\begin{array}{c}\text { Azoxystrobin } \\
\mathrm{mL} \text { per } \mathrm{L}\end{array}$} & \multicolumn{2}{|c|}{$1^{\text {st }}$ order } & \multicolumn{2}{|c|}{$1.5^{\text {th }}$ order } & \multicolumn{2}{|c|}{$2^{\text {nd }}$ order } & \multicolumn{2}{|c|}{ RF $1^{\text {st }}$ order } & \multicolumn{2}{|c|}{ RF $1.5^{\text {th }}$ order } & \multicolumn{2}{|c|}{$\mathrm{RF} 2^{\text {nd }}$ order } & \multicolumn{2}{|c|}{ IPL } & \multirow{2}{*}{ Best fit } \\
\hline & $\mathrm{R}$ & $\mathrm{MR}^{2}$ & $\mathrm{R}$ & $\mathrm{MR}^{2}$ & $\mathrm{R}$ & $\mathrm{MR}^{2}$ & $\mathrm{R}$ & $\mathrm{MR}^{2}$ & $\mathrm{R}$ & $\mathrm{MR}^{2}$ & $\mathrm{R}$ & $\mathrm{MR}^{2}$ & $\mathrm{R}$ & $\mathrm{MR}^{2}$ & \\
\hline 0.25 & - & - & - & - & - & - & - & - & - & - & - & - & - & - & - \\
\hline 1.0 & -0.9821 & 0.3426 & 0.9082 & 0.6433 & -0.8519 & -0.9704 & -0.8895 & -1.7987 & 0.7790 & -0.1051 & 0.7111 & -1.1976 & 0.9638 & 0.8286 & IPL \\
\hline 2.0 & -0.9471 & 0.6678 & -0.9774 & -8.4885 & 0.9797 & -0.9982 & -0.9113 & -1.8521 & -0.9092 & -0.5059 & 0.8835 & -1.0000 & 0.9802 & 0.7599 & IPL \\
\hline
\end{tabular}

$\mathrm{RF}$ - Root function; R - Regression Co efficient; $\mathrm{MR}^{2}$ - Modified $\mathrm{R}^{2}$; IPL - Inverse Power Law

Table 5. Intercept, slope, half life and waiting period of azoxystrobin residues in mango fruits

\begin{tabular}{cccccccccccc}
\hline $\begin{array}{c}\text { Azoxystrobin } \\
\mathrm{mL} \text { per } \mathrm{L}\end{array}$ & $\mathrm{A}$ & $\mathrm{UL}$ & $\mathrm{LL}$ & $\mathrm{B}$ & $\mathrm{UL}$ & $\mathrm{LL}$ & $\mathrm{T}_{0.5}$ & $\mathrm{UL}$ & $\mathrm{LL}$ & $\begin{array}{c}\text { Waiting } \\
\text { periods } \\
\text { (Days) }\end{array}$ & Predicted equation \\
\hline 0.25 & - & - & - & - & - & - & - & - & - & - & - \\
& & & & & & & & & & & \\
$1.0^{*}$ & -0.2496 & 11.8483 & -12.3475 & 3.0570 & 13.8102 & -7.6961 & 1.25 & 2.2550 & 2.25 & 1.92 & $\mathrm{Y}=-0.2496+3.0570 \mathrm{x}$ \\
& & & & & & & & & & & \\
2.0 & 0.2264 & 11.1988 & -10.7461 & 3.8018 & 13.5546 & -5.9511 & 1.20 & 1.7613 & 0.64 & 2.00 & $\mathrm{Y}=0.2264+3.8018 \mathrm{x}$ \\
\hline
\end{tabular}

A - Intercept; B - Slope; UL - Upper Limits; LL -Lower Limits; $\mathrm{T}_{0.5}-$ Half Life; * Half of the LOD value $(0.002 \mu \mathrm{g}$ per $\mathrm{g})$ was substituted by the BDL parameters. 
Table 6. Physico-chemical properties and molecular structure of azoxystrobin

\begin{tabular}{ll}
\hline Structural Formula & \multicolumn{1}{c}{ Azoxystrobin } \\
\hline Chemical Name (IUPAC) & phenoxy)pyrimidin-4-yloxy] \\
phenyl $\}-3$-methoxyacrylate
\end{tabular}

\section{Conclusion}

Thus, azoxystrobin residue in mango fruits was effectively determined by high performance liquid chromatography with UV detection. The results revealed that the half life of azoxystrobin in mango, when sprayed at recommended dose $(1.0 \mathrm{~mL}$ per $\mathrm{L})$ was one day and residue dissipates within three days after spray, thus spraying of azoxystrobin is very unlikely to cause any acute or chronic health risk.

\section{References}

1. Anke, J. F.; Dherwinkler, W.; Steglich, G.; Schramm,E.; J. Antibiotic. 1977, 30, 806.
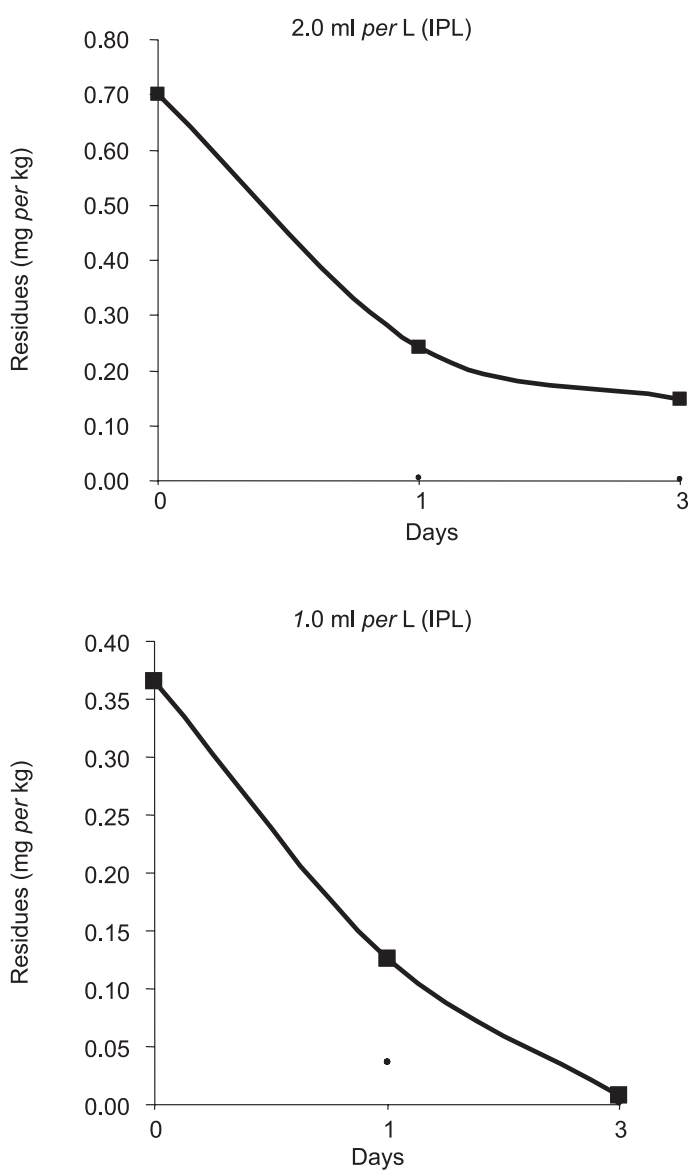

Figure 1. Back transformed decline curve of azoxystrobin in mango fruits

2. Bertlett, W.; John, M.; Chris, R. A.; Godfrey, J. R.; Godwin, A. A.; Steve, P. A.; Heaney, P. S.; Maund, S. J.; Pesticide Outlook 2001, 12, 143.

3. Junior, R. S.; Costa, F. M.; Rosiana, E. M. M.; Nunes, G. H. S.; Filho, J. A.; Miranda, U. S.; Fitopatologia Brasileira 2004, 29, 193.

4. Giza, I.; Sztweirtnia, V.; Acta Chromatographic 2003, 19, 226.

5. http://www.safemeat.com.au/NR/rdonlyres/9ED0AAD4-E203-4E9B9C20-2F806057CE78/0/avocado_mango_Jan06FINAL.pdf

6. Chen, M. F.; Chien, H. P.; Wong, S. S.; Li, G. C.; Plant Prot. Bull. 2004, 46,123. 